\title{
PENGARUH PENERAPAN COLLABORATIVE LEARNING BERBANTU ISPRING PRESENTER TERHADAP HASIL BELAJAR PROGRAM LINEAR
}

\author{
Venty Meilasari \\ Program Studi Pendidikan Matematika, FKIP Universitas Muhammadiyah Kotabumi \\ email: ventymeilasari@gmail.com
}

\begin{abstract}
This research was aimed to investigate the influence of implementation collaborative learning with ispring presenter toward linear programing outcomes. This research was quantitative research. This also used the pre-experimental design with one-group pretest-posttest design. The sample were all students of the $4^{\text {th }}$ of mathematic departement of Universitas Muhammadiyah Kotabumi in academic year 2017/2018. The sample was taken using purposive sampling. The instruments used was linear programing outcomes test. The conclusions of this research was that there is positive influence of implementation collaborative learning with ispring presenter toward linear programing outcomes.
\end{abstract}

Keyword: collaborative learning, ispring presenter, linear programing.

\section{PENDAHULUAN}

Program linear merupakan mata kuliah yang wajib ditempuh oleh mahasiswa program studi pendidikan matematika Universitas Muhammadiyah Kotabumi (UMKO). Matakuliah ini memiliki beban 2 SKS dan ditempuh oleh mahasiswa di semester IV. Sebelum menempuh program linear, mahasiswa harus terlebih dahulu lulus matakuliah Aljabar Linear. Adapun secara garis besar materi yang dikaji pada matakuliah ini, yaitu: (a) Pemecahan masalah program linear dengan cara grafik, aljabar, simpleks; (b) persoalan atau masalah transportasi; dan (c) metode penugasan.

Program linear sangat erat hubungannya dengan kehidupan sehari-hari. Misalnya suatu permasalahan pendistribusian barang dari produsen ke konsumen, dapat lebih mudah diselesaikan dengan program linier. Selain itu, untuk mendapatkan hasil yang optimal, program linear juga dapat digunakan dalam penyelesaian masalah pembagian tugas untuk karyawan. Meskipun demikian, kenyataannya hasil belajar program linear mahasiswa prodi pendidikan matematika UMKO masih belum optimal. Hal itu dapat dilihat pada Tabel 1 berikut. 
Tabel 1

Hasil Belajar Program Linear Tahun Akademik 2016/2017

\begin{tabular}{|c|c|c|}
\hline Rentang Nilai & Angka Mutu & Frekuensi \\
\hline $80-100$ & A & 7 \\
\hline $70-79$ & B & 5 \\
\hline $60-69$ & C & 9 \\
\hline $50-59$ & D & 0 \\
\hline $0-49$ & E & 0 \\
\hline \multicolumn{2}{|c|}{ Jumlah } & 21 \\
\hline
\end{tabular}

Berdasarkan Tabel 1, diketahui bahwa hasil belajar program linear mahasiswa belum optimal. Dari 21 mahasiswa yang mengikuti mata kuliah ini hanya 12 mahasiswa atau 57, 14\% yang mencapai nilai A dan B. Disisi lain sebanyak 9 mahasiswa atau $42,86 \%$ hanya mencapai nilai $\mathrm{C}$ yang berarti cukup.

Berdasarkan pengalaman mengajar program linear, mahasiswa masih mengalami kesulitan dalam membuat model matematika dari soal. Beberapa mahasiswa keliru dalam menentukan variabel dalam model matematika. Penyelesaian soal program linear cenderung panjang dan berulang-ulang seperti pada metode simpleks, masalah transportasi, dan metode penugasan. Hal ini menuntut mahasiswa untuk tekun dan teliti. Suatu kesalahan akan berakibat ke tahap-tahap selanjutnya. Kekeliruan yang dibuat, akan membuat mahasiswa malas untuk mengerjakan kembali.

Selama ini, mahasiswa yang mengalami kesulitan dalam pembelajaran cenderung menjadi tidak bersemangat.
Sebagian merasa segan untuk bertanya kepada dosen tentang materi yang belum dipahami. Sebagian merasa enggan untuk bertanya kepada teman yang sudah paham. Untuk mengatasi hal tersebut, perlu diciptakan kondisi belajar yang memungkinkan terjadi interaksi antara dosen dengan mahasiswa, antarmahasiswa, dan mahasiswa dengan sumber belajar. Salah satu solusi yang dapat digunakan pendidik adalah dengan menerapkan pendekatan Collaborative learning.

Collaborative learning menurut Armiati dan Sastramiharja (2007:29) adalah suatu pendekatan pembelajaran yang digunakan untuk mengajar dan belajar yang melibatkan sekelompok orang yang bekerja sama untuk menyelesaikan masalah, melengkapi tugas atau menghasilkan produk. Pendekatan pembelajaran ini, didasarkan pada ide bahwa belajar adalah aksi sosial alamiah dengan para partisipan yang berdiskusi, sehingga melalui diskusi yang terjadi proses belajar berlangsung.

Pembelajaran kolaboratif bukan merupakan hal yang baru di dunia pendidikan. Beberapa aktivitas pembelajaran kolaboratifface to face yang sudah familiar dan digunakan diberbagai jenjang pendidikan adalah studi kasus, role playing, Dyad, dan Jigsaw. Selain pembelajaran face to face, pembelajaran kolaboratif dapat juga dilakukan secara online. 
Collaborative learning didasarkan pada teori konstruktivisme sosial yang diungkapkan oleh Vygotsky. Menurut Vygotsky (1978), dalam diri seseorang terdapat zone of proximal development yang merupakan jarak antara tingkat perkembangan sebenarnya yang ditentukan oleh problem solving independen dengan tingkat perkembangan potensial yang ditentukan melalui problem solving dengan bimbingan orang yang lebih dewasa atau adanya kolaborasi dengan teman sebaya yang lebih mampu. Selanjutnya menurut Khoiriyah (2016:15) pada pendekatan kolaboratif ini, proses pembelajaran ditekankan pada diskusi dan keaktifan peserta didik untuk memahami materi.

Diskusi dan keaktifan merupakan aktivitas yang ada pada cooperative learning dan collaborative learning. Meskipun demikian, terdapat perbedaan pada kedua pendekatan pembelajaran tersebut. Pada cooperative learning, suatu kelompok pembelajaran membagi tugas dan merangkai tugas tersebut dalam satu bagian utuh yang menjadi hasil kerja kelompok. Seluruh anggota tidak memiliki pendapat yang berbeda. Berbeda dengan cooperative learning, pada collaborative learning masing-masing anggota kelompok mengerjakan tugas yang diberikan dan dilanjutkan dengan proses diskusi antarmahasiswa maupun antara mahasiswa dengan dosen untuk mencapai suatu kesepakatan jawaban tugas tersebut.
Selain penerapan pendekatan Collaborative learning, perlu diterapkan teknologi digital yang dapat disajikan secara interaktif dan menarik. Salah satu tool yang dapat digunakan adalah ispring presenter. Selain membuat media pembelajaran menjadi lebih menarik, tool ini juga mudah didistribusikan dalam format flash, yang dapat digunakan dimanapun dan dioptimalkan dalam penggunaan web. Tool ini juga dapat diaplikasikan untuk merekam dan mensinkronisai video presenter, menambahkan flash dan video youtube dengan membuat navigasi dan desain yang unik.

Ispring Presenter menurut Hernawati (2010:1) merupakan suatu tool yang mengubah file presentasi menjadi bentuk flash dan bentuk SCORM/AICC, yaitu bentuk yang biasa digunakan dalam pembelajaran dengan e-learning LMS (Learning Management System). Perangkat lunak ini secara mudah dapat diintegrasikan dalam Microsoft powerpoint sehingga penggunaannya tidak membutuhkan keahlian yang rumit. Beberapa fitur yang terdapat dalam Ispring Presenter adalah sebagai berikut.

1. Ispring presenter bekerja sebagai add-ins powerpoint, untuk menjadikan file powerpoint lebih menarik dan interaktif berbasis flash dan dapat dibuka dihampir setiap komputer atau flatform.

2. Dikembangkan untuk mendukung $e$ learning. Ispring presenter dapat 
menyisipkan berbagai bentuk media, diantaranya dapat merekam dan mensinkronisasi video presenter, menambahkan flash dan video youtube, mengimpor atau merekam audio, menambahkan informasi pembuat presentasi dan logo perusahaan, serta membuat navigasi dan desain yang unik.

3. Mudah didistribusikan dalam format flash, yang dapat digunakan dimanapun dan dioptimalkan untuk web.

4. Membuat kuis dengan berbagai jenis pertanyaan yaitu, true/false, multiple choice, multiple reason, type in, matching, sequence, numeric, fill in the blank, dan multiple choice text.

Berdasarkan uraian pada pendahuluan, rumusan masalah dalam penelitian ini adalah "Adakah Pengaruh Penerapan Collaborative Learning Berbantu Ispring Presenter terhadap Hasil Belajar Program Linear?”

\section{METODE PENELITIAN}

Penelitian ini merupakan penelitian kuantitatif. Adapun desain yang digunakan pre-experimental design dengan memilih One-Group Pretest-Posttest Design. Menurut Sugiyono (2013:110-111) desain tersebut merupakan desain dengan satu kelompok yang diberi pretest dan posttest. Dengan demikian hasil perlakuan dapat lebih akurat dengan membandingkan keadaan sesudah dengan keadaan sebelum diberi perlakuan.

Populasi dalam penelitian ini adalah seluruh mahasiswa prodi pendidikan matematika Universitas Muhammadiyah Kotabumi tahun akademik 2017/2018. Sampel yang digunakan adalah semester IV program studi pendidikan matematika. Adapun teknik sampling yang digunakan adalah purposive sampling. Sugiyono (2013:124) menyatakan bahwa "sampling purposive adalah teknik penentuan sampel dengan pertimbangan tertentu”. Sampel diambil dengan pertimbangan bahwa mata kuliah program linear dipelajari oleh mahasiswa semester IV prodi pendidikan matematika.

Teknik pengumpulan data yang digunakan dalam penelitian adalah tes tertulis. Instrumen yang digunakan dalam penelitian adalah tes uraian berupa tes hasil belajar yang terdiri dari pretest dan posttest. Pretest merupakan tes yang diberikan sebelum subjek diberi perlakuan, sedangkan posttest merupakan tes yang diberikan setelah subjek diberi perlakuan. Rerata pretest kemudian dibandingkan dengan rerata postest untuk mendapatkan jawaban dari pertanyaan penelitian.

Analisis data yang digunakan adalah uji t untuk sampel berpasangan. Menurut Sugiyono (2013:274) formulanya adalah sebagai berikut. 


$$
t=\frac{\overline{X_{1}}-\overline{X_{2}}}{\sqrt{\frac{s_{1}^{2}}{n_{1}}+\frac{s_{2}^{2}}{n_{2}}-2 r\left(\frac{s_{1}}{\sqrt{n_{1}}}\right)\left(\frac{s_{2}}{\sqrt{n_{2}}}\right)}}
$$

Dengan

$$
r=\frac{n \sum x_{i} y_{i}-\left(\sum x_{i}\right)\left(\sum y_{i}\right)}{\sqrt{\left\{n \sum x_{i}^{2}-\left(\sum x_{i}\right)^{2}\right\}\left\{n \sum y_{i}^{2}-\left(\sum y_{i}\right)^{2}\right\}}}
$$

(Sugiyono, 2013:255)

Sebelum data dianalisis, sebelumnya terlebih dahulu dilakukan uji prasyarat, yaitu uji normalitas dan homogenitas. Uji normalitas dilakukan dengan menggunakan uji Liliefors. Selanjutnya uji homogenitas dengan uji kesamaaan varians. Adapun taraf siginfikansi yang digunakan adalah 5\%.

\section{HASIL DAN PEMBAHASAN}

Penelitian dilakukan pada semseter genap tahun akademik 2017/2018. Saat itu Universitas Muhammadiyah Kotabumi (UMKO) masih menjadi STKIP Muhammadiyah Kotabumi. Adapun pelaksanaan penelitian tepatnya dilakukan setelah ujian tengah semester (UTS) sampai dilaksanakan ujian akhir semester (UAS) semester genap. Data UTS menjadi data pretest dan data UAS menjadi data postes. Adapun hasil penelitian dapat dilihat pada Tabel 2 berikut.

Tabel 2

Rangkuman Hasil Penelitian

\begin{tabular}{|c|c|c|}
\hline Interval Nilai & Pretest & Postest \\
\hline $41-50$ & 5 & 1 \\
\hline $51-60$ & 1 & 4 \\
\hline $61-70$ & 5 & 1 \\
\hline $71-80$ & 3 & 6 \\
\hline
\end{tabular}

\begin{tabular}{|c|c|c|}
\hline $81-90$ & 0 & 2 \\
\hline $91-100$ & 2 & 2 \\
\hline Jumlah & 16 & 16 \\
\hline $\begin{array}{c}\text { Nilai } \\
\text { minimum }\end{array}$ & 42 & 50 \\
\hline $\begin{array}{c}\text { Nilai } \\
\text { maksimum }\end{array}$ & 100 & 100 \\
\hline Rata-rata & 64,063 & 73,063 \\
\hline Varians & 366,729 & 271,663 \\
\hline
\end{tabular}

Berdasarkan Tabel 2, diketahui bahwa rerata pretest adalah 64,06 dan rerata postest sebesar 73,06. Nilai minimum pada pretest 42 dan 50 pada postes. Adapun nilai maksimum yang diperoleh baik pada pretes maupun postes adalah 100. Data tersebut kemudian dianalisis dengan uji $\mathrm{t}$ untuk melihat ada atau tidaknya pengaruh penerapan Collaborative Learning Berbantu Ispring Presenter terhadap Hasil Belajar Program Linear. Namun sebelum itu, dilakukan uji prasyarat analisis, yaitu uji normalitas dan uji homogenitas.

Prasyarat pertama adalah sampel harus berasal dari populasi yang berditribusi normal. Pengujian normalitas yang dilakukan adalah dengan menggunakan uji Liliefors. Adapun rangkuman hasil uji normalitas sebagai berikut.

Tabel 3

Rangkuman Uji Normalitas

\begin{tabular}{|l|l|l|}
\hline & $\mathrm{L}_{\mathrm{hit}}$ & $\mathrm{L}_{\text {tabel }}$ \\
\hline Pretest & 0,188 & 0,213 \\
\hline Postest & 0,176 & 0,213 \\
\hline
\end{tabular}

Tabel 3 menunjukkan bahwa $\mathrm{L}_{\text {hit }}$ untuk data pretes adalah 0,188 dan $\mathrm{L}_{\text {hit }}$ untuk 
data postes sebesar 0,176. Jika kedua Lhit tersebut dibandingkan dengan $\mathrm{L}_{\text {tabel, }}$ diperoleh bahwa $\mathrm{L}_{\text {hit }}$ bernilai lebih kecil daripada $\mathrm{L}_{\text {tabel. }}$ Oleh karena itu, disimpulkan bahwa baik sampel pretes maupun postes berasal dari populasi yang berdistribusi normal.

Uji prasyarat analisis yang kedua adalah uji homogenitas. Uji yang dilakukan dengan menggunakan rumus kesamaan varians yaitu, varians terbesar dibagi dengan varians terkecil. Berdasarkan Tabel 2 diketahui bahwa varians pretest adalah 366,729 dan varians postes adalah 271,663. Oleh karena itu, diperoleh nilai $F_{\text {hit }}=1,350$ dan $F_{\text {tabel }}=2,41$. Karena $F_{\text {hit }}<F_{\text {tabel }}$ maka dapat disimpulkan bahwa kedua sampel homogen.

Selanjutnya dilakukan analisis data dengan menggunakan uji t. Sebelumnya terlebih dahulu dihitung nilai $r$ yang kemudian disubstitusikan ke dalam rumus uji t . Rangkuman hasil analisis data dapat dilihat pada Tabel 4 berikut.

Tabel 4

Rangkuman Analisis Uji t

\begin{tabular}{|c|c|c|}
\hline Nilai $\mathrm{r}$ & $t_{\text {hit }}$ & $t_{\text {tabel }}(\alpha=5 \%)$ \\
\hline 0,606 & 2,251 & 1,697 \\
\hline
\end{tabular}

Berdasarkan Tabel 4, diketahui bahwa $t_{\text {hit }}=2,251$ sedangkan $t_{\text {tabel }}=1,697$. Ini berarti bahwa $t_{\text {hit }}>t_{\text {tabel }}$. Oleh karenanya disimpulkan bahwa ada pengaruh positif penerapan Collaborative Learning Berbantu
Ispring Presenter terhadap Hasil Belajar Program Linear.

Adanya pengaruh yang positif pada hasil belajar program linear jelas dapat dicapai. Penerapan pembelajaran kolaboratif menciptakan kondisi pembelajaran yang aktif. Mahasiswa dapat saling berkolaborasi baik antarmahasiswa maupun dengan dosen.

Berdasarkan aktivitas saat pembelajaran, beberapa mahasiswa merasa lebih nyaman untuk bertanya dan lebih memahami penjelasan dari teman sebaya (peer teaching). Sebagian lagi ada yang merasa segan untuk bertanya kepada orang lain baik teman maupun dosen karena takut dengan anggapan yang akan muncul. Setelah diterapkannya pembelajaran kolaboratif, sedikit demi sedikit muncul kebiasaan mahasiswa untuk berkolaborasi. Mahasiswa mulai berkolaborasi dengan teman sekelompoknya, teman dari kelompok lain, dan bahkan dengan dosen pegampu matakuliah. Aktivitas dikusi pun semakin meningkat. Hal ini berdampak pada tingkat pemahaman materi mahasiswa yang lebih baik daripada sebelumnya.

Selanjutnya selain penerapan pembelajaran kolaboratif, penggunaan ispring presenter juga ikut memberikan andil. Dengan bahan ajar yang lebih menarik menumbuhkan minat bagi mahasiswa untuk mempelajari materi yang disiapkan. Selanjutnya kemudahan dalam pendistribusian media memberikan kemudahan 
bagi mahasiswa untuk mengakses bahan ajar di kelas maupun di rumah.

\section{SIMPULAN}

Berdasarkan hasil penelitian dan pembahasan, dapat disimpulkan bahwa ada pengaruh penerapan Collaborative Learning Berbantu Ispring Presenter terhadap Hasil
Belajar Program Linear. Proses kolaborasi membuat mahasiswa menjadi lebih aktif berdiskusi dalam pembelajaran. Selanjutnya media ispring presenter yang membuat bahan ajar lebih menarik dan mudah didistribusikan memumbuhkan minat mahasiswa dan kemudahan dalam mengaksesnya.

\section{DAFTAR RUJUKAN}

Armiati, Sari dan Sastramihardja, Husni. 2007. Collaborative Learning Framework. Makalah disajikan dalam Seminar Nasional Aplikasi Teknologi Informasi 2007 (SNATI 2007). Yogyakarta, 16 Juni 2007.

Hernawati, Kuswari. 2010. Modul Pelatihan Ispring Presenter. Disampaikan dalam kegiatan PPM dengan judul: Pelatihan Pembuatan Media Pembelajaran Interaktif dengan Perangkat Lunak Ispring Presenter bagi Guru Sekolah Menengah pada Tanggal 23 Juli 2010 di laboratorium Komputer Jurdik Matematika FMIPA UNY.

Khoiriyah, Annisatul. 2016. "Pembelajaran Kolaboratif pada Matematika untuk Membentuk Karakter Generasi”. Jurnal Matematika dan Pendidikan Matematika. Vol I No 1. Hal 1322.

Sugiyono. 2013. Metode Penelitian Pendidikan: Pendekatan Kuantitatif, Kualitatif, dan R\&D. Bandung: Alfabeta.

Vygotsky, L. (1978). Interaction between Learning and Development. From:Mind and Society (pp 79-91). Cambridge, MA: Harvard University Press. 